\title{
SISTEM INFORMASI ERP (ENTERPRISE RESOURCES PLANNING) UNTUK MENDUKUNG FUNGSI BISNIS PADA PT. CIPTA MANDIRI ELEKTRINDO
}

\author{
Heru Purwanto ${ }^{1}$, Albertus Agung Raharja ${ }^{2}$ \\ Sistem Informasi, Universitas Bina Sarana Informatika ${ }^{1}$ \\ Sistem Informasi, STMIK Nusa Mandiri ${ }^{2}$ \\ Heru.hrp@bsi.ac.id ${ }^{1}$ \\ Agungraharja55@gmail.com²
}

Submitted May 22, 2019; Revised July 15, 2019; Accepted July 24, 2019

\begin{abstract}
Abstrak
Perkembangan teknologi informasi yang begitu cepat berdampak pada perilaku dan budaya dalam bisnis, dimana konsumen diberikan kemudahan oleh sebuah sistem. Menjadi sebuah tantangan sebuah perusahaan untuk dapat mengimbangi dan berperan aktif agar dapat bersaing dalam dunia bisnis. Dalam penelitian ini peneliti mencoba memodelkan konsep ENTERPRISE RESOURCES PLANNING ERP sebagai landasan dasar proses bisnis yang terintegrasi. Diagaram usecase dan squence digunakan sebagai modeling proses bisnis . implementasi pengembangan perangkat lunak yang melibatkan modul , view dan controler yang dikuatkan dengan rancangan Logical record structure LRS digunakan untuk menampilkan keterhubungan database. Pe ngujian basis path memberikan hasil dengan nilai 3 merupakan suatu penggunaan algoritma dalam katergori low risk. Pengujian validasi dengan hasil valid menjadi sebuah respon dengan terpenuhi akan kebutuhan Fungsional sistem. Sedangkan dari hasil pengujian kebutuhan non functional terkait dengan usability melalui perhitungan $\mathrm{T}$ test dimana $\mathrm{t}$ hit $=4.580>\mathrm{t} 0,05 ; 9=2,265$, menunjukan aplikasi sistem dapat diterima dan berpengaruh terhadap efesiensi dan efeksifitas kerja.
\end{abstract}

Kata Kunci : ERP,Modelling,basis path,T-test

\begin{abstract}
The development of information technology that has an impact on behavior and culture in business can be so easy and fast. It becomes a challenge for a company to be able to balance and play an active role in order to compete in the business world. In this study researchers tried to model the ERP concept as the basic foundation of integrated business processes. The usecase and squares diagrams are used as business process modeling. the implementation of software development involving modules, views and controllers reinforced with the LRS design is used to display database connectivity. The basis path test gives results with value 3 is an use of algorithms in low risk categories. Validation testing with valid results becomes a response with fulfilled functional requirements. While the results of testing non-functional requirements related to usability through the calculation of the $T$ test where $t$ hit $=4.580>t 0.05,9=2.265$, indicating that the system application is acceptable and influences the efficiency and effectiveness of work.
\end{abstract}

Keywords : ERP,Modelling,basis path,T-tes

\section{PENDAHULUAN}

PT. Cipta Mandiri Elektrindo merupakan perusahaan swasta yang bergelut pada sektor bisnis electrical power, mechanical transmisson, dan fluida. PT. Cipta Mandiri Elektrindo Dalam menjalankan Bisnis sudah menggunakan komputer namun masih belum optimal, sehingga pendataan atau pencatatan data-data transaksi perusahaan tidak bisa diakses secara terintegrasi oleh bagian atau unit kerja yang membutuhkan informasi data-data tersebut. Sebagai contoh, bagian sales ketika menerima pemesanan dari customer 
harus mencari informasi kebagian gudang untuk mendapat data barang yang diinginkan. Contoh lain untuk pembuatan dokumen dilakukan melalui format excel yang riskan akan kesalahan seperti pengetikan no faktur dan surat jalan pengiriman barang. Oleh karena itu diperlukan model sistem informasi yang memungkinkan untuk mengotomasi dan mengintegrasi bisnis prosesnya dalam kegiatan bisnis perusahaan [1].

Persaingan bisnis yang ketat dan kompetitif menuntut perusahaan untuk lebih meningkatkan kinerja diberbagai bagian atau departemen pada perusahaan [2]. Untuk menciptakan hal tersebut diperlukan sistem informasi yang mengintegrasikan manajemen yang efesien dan efektif [3].

Menurut [4] Penggunaan Sistem informasi berbasis ERP [5] yang terpadu sangat mendukung fungsi kegiatan bisnis yang berdampak pada berkurangnya pengeluaran untuk biaya operasional dan membantu pimpinan dalam proses pengambilan keputusan) [6] untuk negosiasi yang lebih baik.

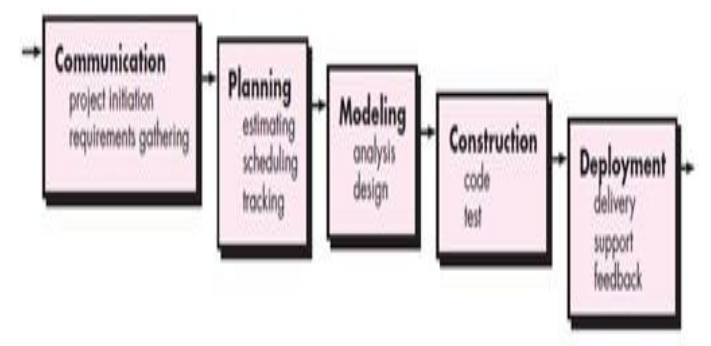

Gambar 1. Model Waterfall

Model waterfall digunakan dalam perancangan dan pembuatan program aplikasi. Langkah awal dalam kegiatan ini adalah membangun komunikasi dengan user, untuk menganalisis permasalahan dan serta mengumpulkan data-data serta membantu dalam mendeskripsikan fitur yang diperlukan. Tahap selanjutnya perancanaan merupakan kegiatan estimasi teknis dan sumber daya yang diperlukan. Tahapan Modelling memberikan gambaran struktur kode dan desain interface. Tahapan desain menggunakan UML (unified modeling language) dan LRS (Logical Record Structure), tujuannya memberikan pemahaman akan produk yang akan dihasilkan.Constract merupakan Code generation pada tahapan selanjutnya dengan menggunakan software PHP dan Mysql untuk merancang dan membuat aplikasi. Deployment merupakan tahapan akhir yaitu implementasi dan evaluasi software, dimana pengujian dan implementasi dilakukan dengan melihat hasil dari akurasi data yang dihasilkan baik transaksi maupun laporan.

Menurut Davenport dalam [4] sistem Enterprise resource planning (ERP) menyediakan sebuah platform untuk mengintegrasikan proses dan data. Sistem ERP dapat meningkatkan pendapatan perusahaan melalui peningkatan kinerja perusahaan dengan proses yang efektif dan efesien [8].

\section{METODE PENELITIAN}

Metode kualitatif dengan pendekatan deskriptif menjadi pilihan untuk penelitian ini, dimana kerja unit antar bagian akan lebih mudah untuk saling terintegrasi pada proses transaksi [9].

\section{Metode pengembangan sistem}

Model waterfall disebut juga sebagai model siklus hidup klasik. Model ini memungkinkan pemecahan misi pengembangan yang rumit menjadi beberapa langkah logis (desain, kode, pengujian, dan seterusnya) dengan beberapa langkah yang pada akhirnya menjadi produk akhir yang siap pakai [10]. 
3. HASIL DAN PEMBAHASAN

Perancangan diawali dengan menggunakan diagram usecase

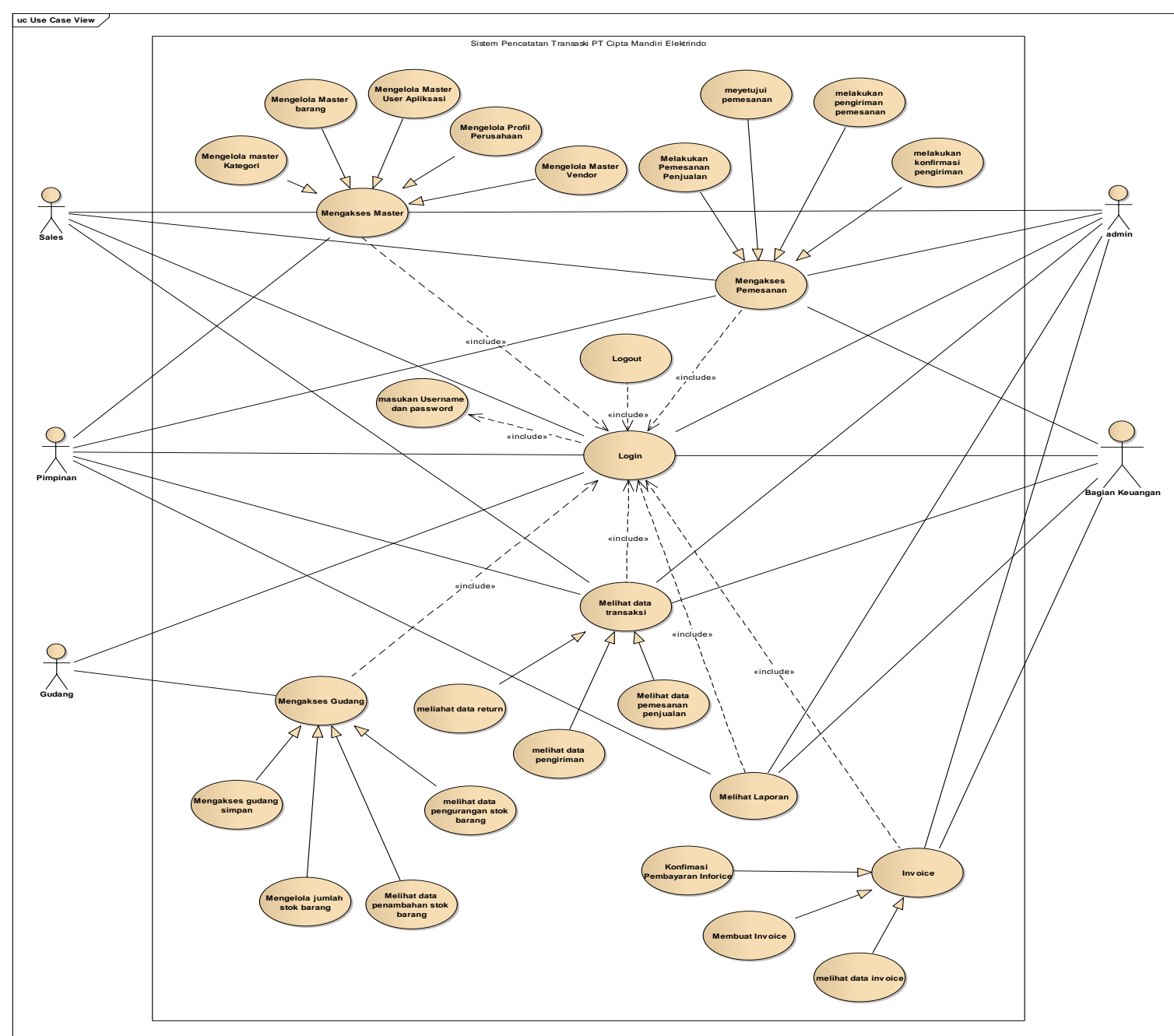

Sumber : Data pengolahan Penelitian

Gambar 2. Diagram Usecase Transaksi

Usecase memberikan gambaran sebuah diagram terhadap kelakuan sebuah sistem. Setelah berhasil login maka actor dapat mengelola sesuai dengan fungsi yang disediakan.

\section{Tabel 1. Deskripsi Usecase}

\begin{tabular}{lll}
\hline NO & Nama Use Case & Keterangan \\
\hline 1 & $\begin{array}{l}\text { Melakukan } \\
\text { Login }\end{array}$ & $\begin{array}{l}\text { Fungsi validasi masuk ke } \\
\text { dalam menu utama sistem. }\end{array}$ \\
\hline 2 & $\begin{array}{l}\text { Melakukan } \\
\text { logout }\end{array}$ & keluar dari menu utama sistem. \\
\hline 3 & Masukan & Berfungsi dalam \\
& username dan & memasukankan username dan \\
password & $\begin{array}{l}\text { password untuk dapat masuk } \\
\text { ke dalam sistem }\end{array}$ \\
\hline 4 & Mengelola data & $\begin{array}{l}\text { Merupakan use case utama. } \\
\text { Terdiri dari master kategori, } \\
\text { master barang, master vendor, }\end{array}$ \\
& &
\end{tabular}

\begin{tabular}{|c|c|c|}
\hline & & $\begin{array}{l}\text { master user aplikasi dan profile } \\
\text { perusahaan. Proses pengolahan } \\
\text { data master tujuannya untuk } \\
\text { update data seperti menambah, } \\
\text { mencari, mengubah dan } \\
\text { menghapus data pada tiap } \\
\text { kategori }\end{array}$ \\
\hline 5 & $\begin{array}{l}\text { Mengelola } \\
\text { profile } \\
\text { 'perusahaan }\end{array}$ & $\begin{array}{l}\text { Berfungsi untuk menampilkan } \\
\text { profil perusahaan }\end{array}$ \\
\hline 6 & $\begin{array}{l}\text { Mengelola } \\
\text { transaksi }\end{array}$ & $\begin{array}{l}\text { use case utama. Terdiri dari } \\
\text { pemesanan } \\
\text { menyetujui penjualan, } \\
\text { pengiriman penjualan, dan } \\
\text { konfirmasi pengiriman }\end{array}$ \\
\hline 7 & $\begin{array}{l}\text { Membuat } \\
\text { pemesanan } \\
\text { penjualan }\end{array}$ & $\begin{array}{l}\text { Fungsi yang diberikan untuk } \\
\text { sales, dalam mengolah data } \\
\text { pemesanan dan penjualan }\end{array}$ \\
\hline 8 & $\begin{array}{l}\text { Menyetujui } \\
\text { memesanan }\end{array}$ & $\begin{array}{l}\text { Fungsi untuk konfirmasi } \\
\text { pesanan yang diajukan untuk } \\
\text { disetujui }\end{array}$ \\
\hline
\end{tabular}




\begin{tabular}{|c|c|c|}
\hline 9 & $\begin{array}{l}\text { Membuat } \\
\text { pengiriman }\end{array}$ & $\begin{array}{l}\text { Fungsi untuk permintaan dan } \\
\text { pengiriman barang ke gudang }\end{array}$ \\
\hline 10 & $\begin{array}{l}\text { Melakukan } \\
\text { konfirmasi } \\
\text { pengiriman }\end{array}$ & $\begin{array}{l}\text { Fungsi untuk mengkonfirmasi } \\
\text { pengiriman, berdasarkan status } \\
\text { pesanan, pemesanan yang } \\
\text { telah dikirim akan dikonfirmasi } \\
\text { sudah sesuai atau belum } \\
\text { dengan pesanan. Dan apakah } \\
\text { diperlukan retur dalam } \\
\text { pengiriman tersebut. }\end{array}$ \\
\hline 11 & $\begin{array}{l}\text { Melihat data } \\
\text { transaksi }\end{array}$ & $\begin{array}{l}\text { use case utama. Untuk melihat } \\
\text { data pemesanan, data } \\
\text { pengiriman, penjualan dan data } \\
\text { retur. }\end{array}$ \\
\hline 12 & $\begin{array}{l}\text { Mengelola } \\
\text { Gudang }\end{array}$ & $\begin{array}{l}\text { use case utama. Untuk } \\
\text { mengakses gudang pengelolaan } \\
\text { jumlah stok barang, update data } \\
\text { barang yang dilakukan oleh } \\
\text { bagian gudang }\end{array}$ \\
\hline 13 & $\begin{array}{l}\text { Mengelola } \\
\text { invoice }\end{array}$ & $\begin{array}{l}\text { Fungsi use case utama. Terdiri } \\
\text { dari data invoice, membuat } \\
\text { tagihan invoice, dan konfirmasi } \\
\text { pembayaran invoice yang } \\
\text { dilakukan }\end{array}$ \\
\hline 14 & Melihat laporan & $\begin{array}{l}\text { Berfungsi untuk } \\
\text { laporan penjualan }\end{array}$ \\
\hline
\end{tabular}

\section{Perancangan Modul}

Controller, view dan modul menjadi class yang dapat menampilkan data hasil dari keterhubungan controller dengan database.

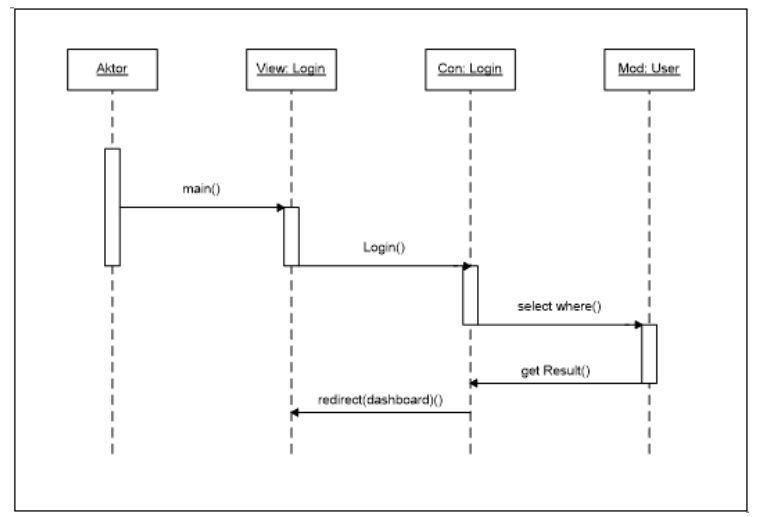

Sumber: Data pengolahan Penelitian

Gambar 3. Tampilan Implementasi Class Controller, View dan Modul

\section{Perancangan Basis Data}

Perancangan dibuat melalui diagram logical Record Structure (LRS) untuk perancangan dan mengimplementasikan basis Data.

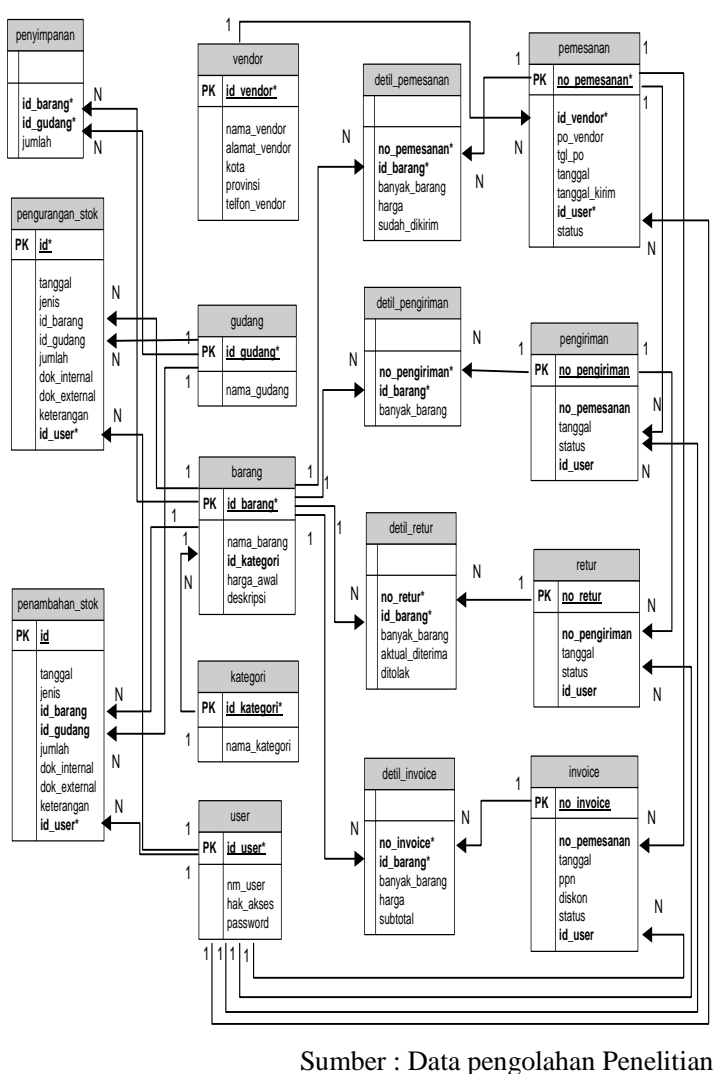

Gambar 4. Rancangan Implementasi Basis

Data

Setiap tabel memiliki memiliki elemen data dan tipe data. Key pada tabel berguna untuk memberikan keterhubungan antara tabel yang satu dengan yang lainnya.

\section{Implementasi Antar Muka}

Form login digunakan untuk validasi user yang berhak masuk untuk menggunakan fasilitas yang disediakan.

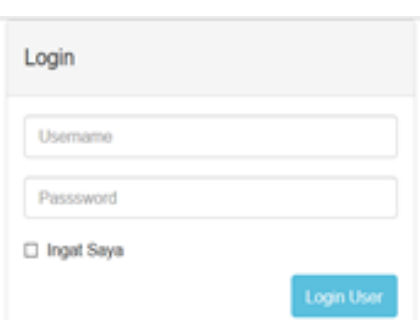

Sumber:Data pengolahan penelitian Gambar 5. Tampilan Halaman Login 


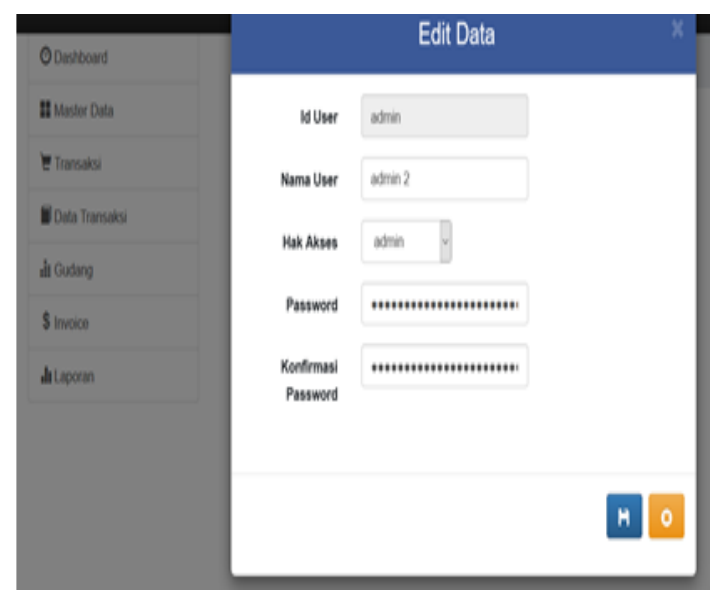

Sumber : Data pengolahan penelitian

Gambar 6.Tampilan Pengaturan User

Tampilan pengaturan user digunakan oleh sistem untuk mengatur level hak akses user

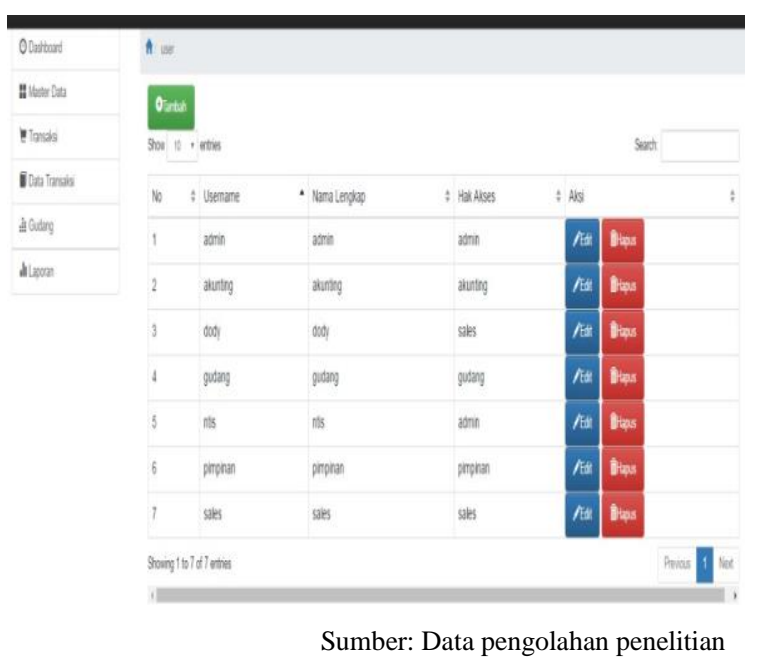

Gambar 7. Tampilan Master User Aplikasi

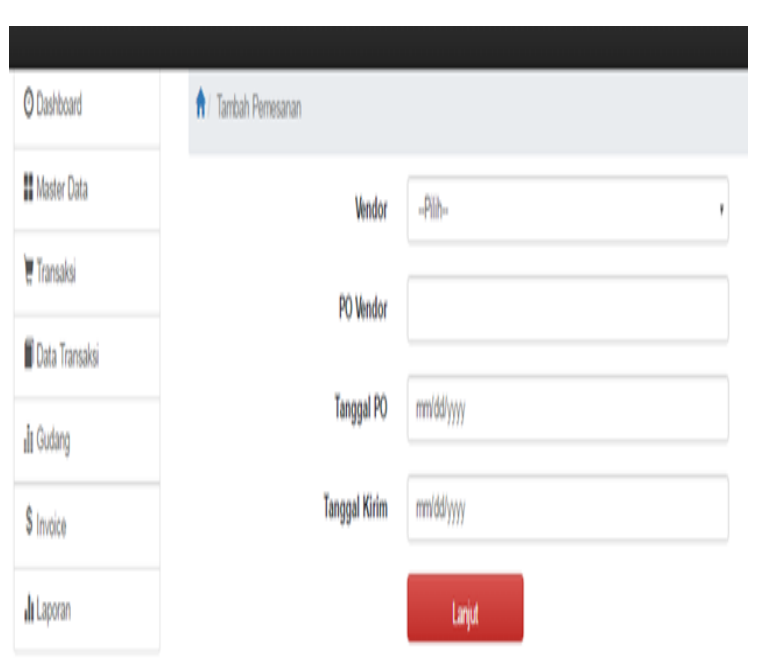

Sumber: Data pengolahan penelitian

\section{Gambar 8. Antar Muka Transaksi Pemesanan}

Bagian administrasi akan melakukan input pemesan dari pelanggan sesuai dengan pesanan.

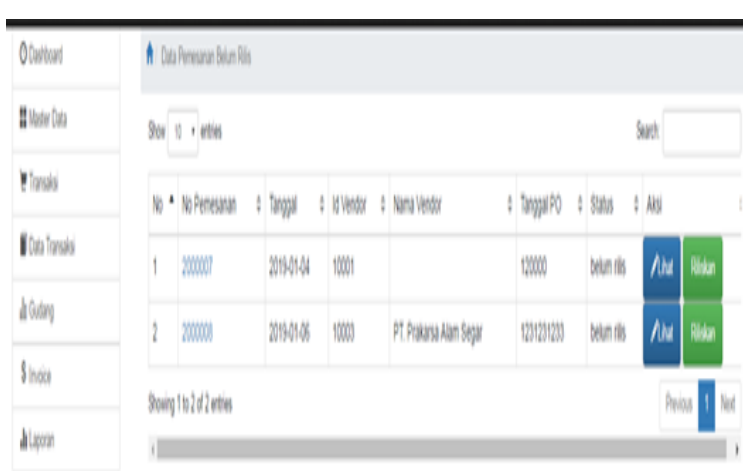

Sumber :Data pengolahan penelitian

\section{Gambar 9. Antar Muka acc Pemesanan}

Bagian akunting akan melihat dan meriliskan atau menyetujui pemesanan. Ada beberapa kegiatan dalam proses pengiriman, bagian administrasi akan melakukan input form pengiriman. 


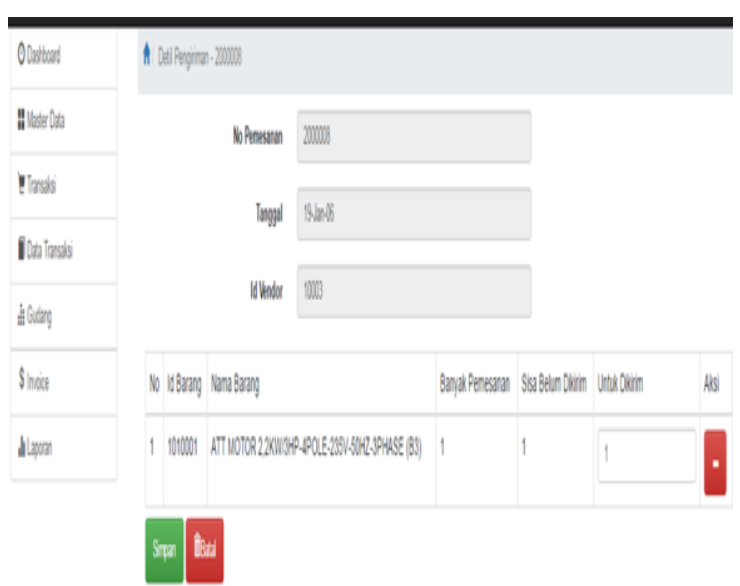

Sumber Data pengolahan penelitian

Gambar 10. Antar Muka Pengiriman Barang

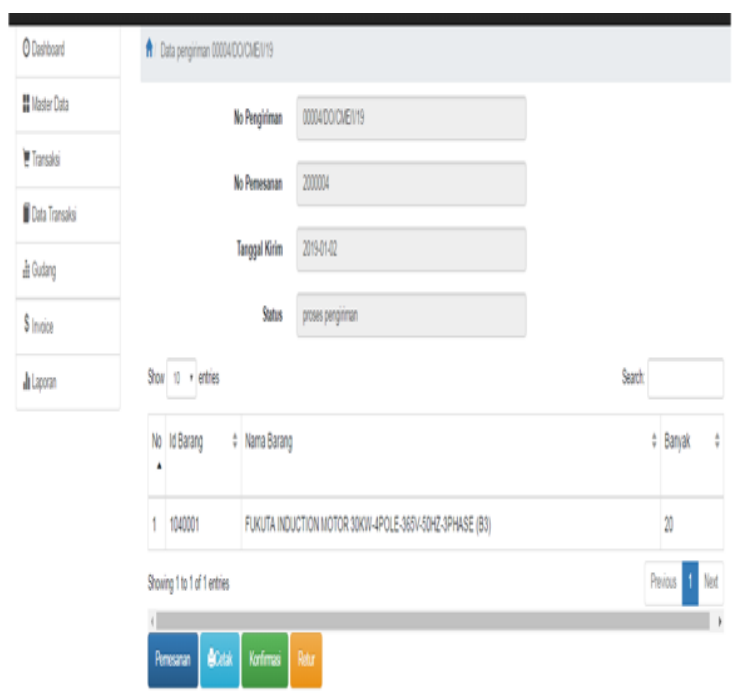

Sumber:Data pengolahan penelitian

Gambar 11. Antar Muka Konfirmasi Pengiriman

Antar muka konfirmasi pengiriman berguna untuk memberikan informasi status pengiriman apakah pengiriman masih dalam proses atau sudah selesai dikirimkan.

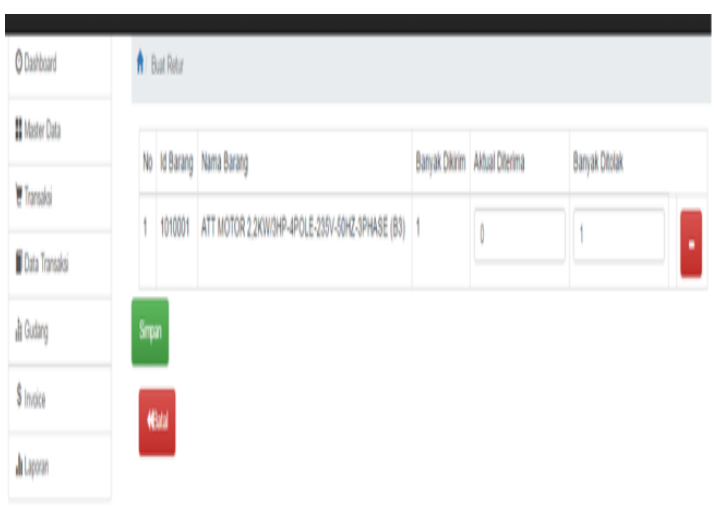

Sumber : Data pengolahan penelitian Gambar 12. Antar Muka Retur Barang

Bila dalam pengiriman ada ketidaksesuaian maka proses retur dilakukan.

Kegiatan pemesanan dan pembelian barang harus memiliki data yang selalu update. Bagian Gudang berperan penting dalam mengecek data tersebut.

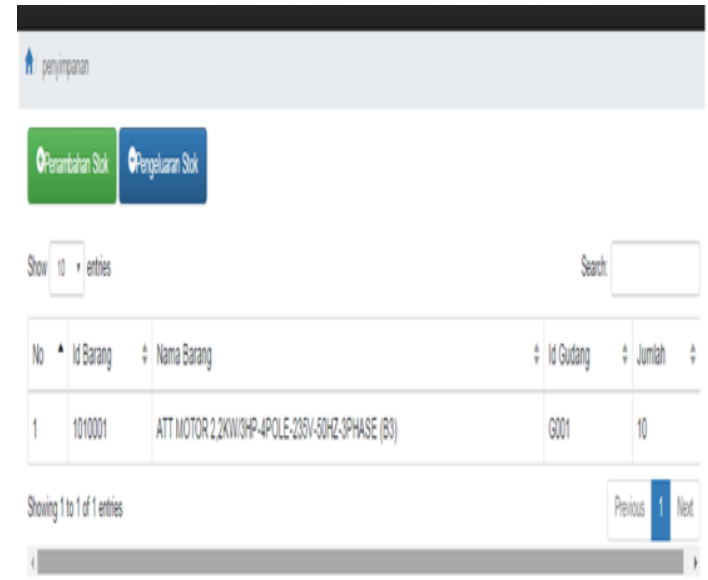

Sumber: Data pengolahan penelitian

Gambar 13. Antar Muka Stok Barang 


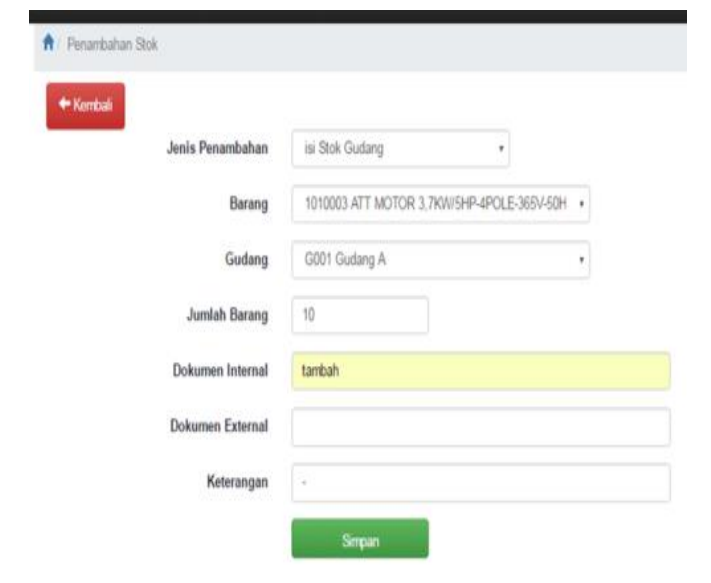

Sumber: Data pengolahan penelitia Barang

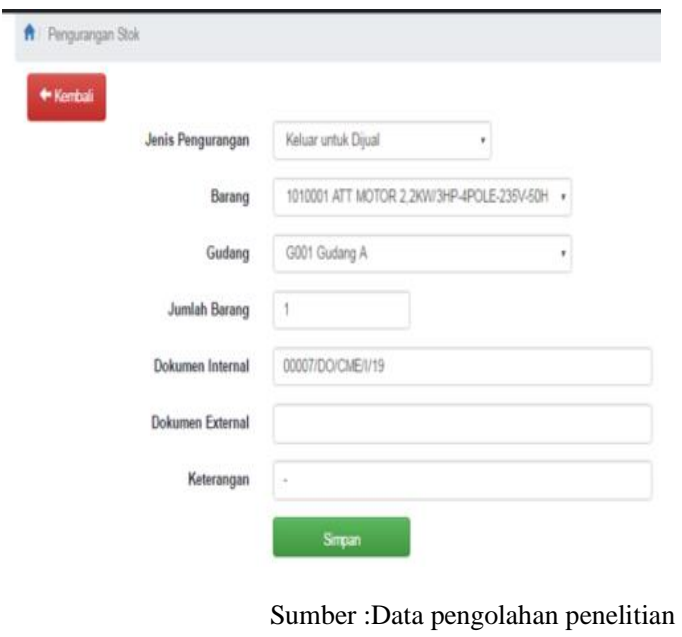

Gambar 15. Antar Muka Data Pengurangan Stok Data Barang

\section{Pembuatan Laporan}

Bagian akunting diberikan kewenangan untuk dapat membuat laporan transaksi pemesanan dan penjualan.

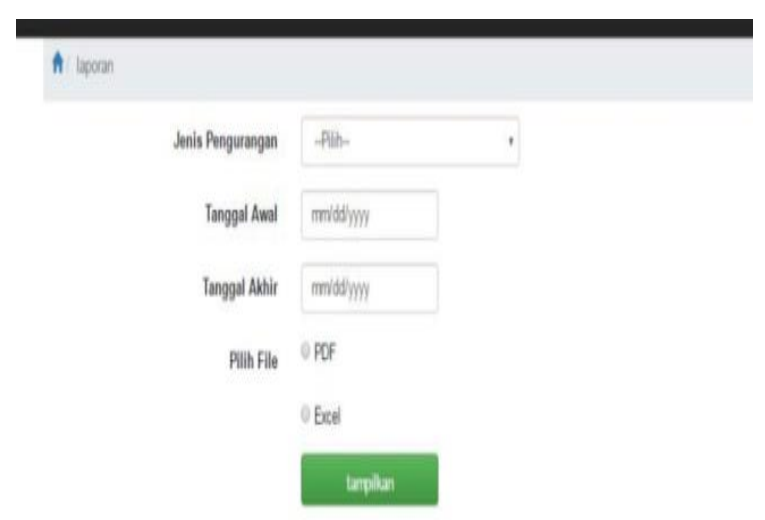

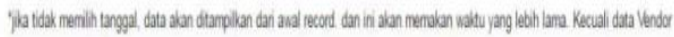

Sumber:Data pengolahan penelitian

Gambar 16. Antar Muka Pembuatan

Laporan

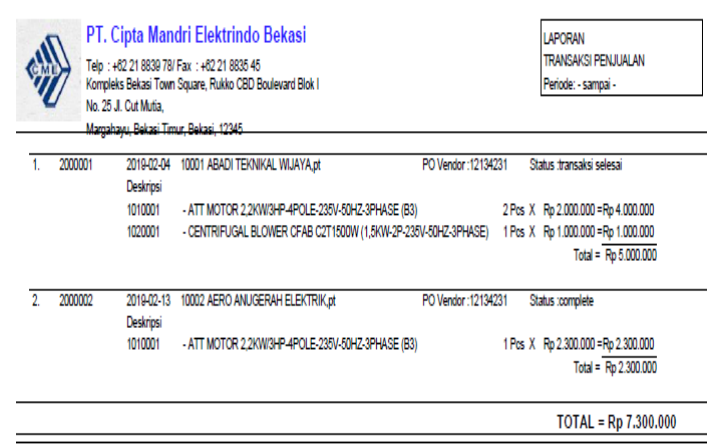

Belas; 1906:-18

akuning

Sumber:Data pengolahan penelitian

Gambar 17. Tampilan Laporan

\section{Pengujian Basis Path}

Pengujian ini digunakan untuk memberikan informasi tentang kompleksitas algoritma yang diterapkan didalam sebuah modul sistem. Melalui perhitungan beberapa area dalam bentuk graph dikenal dengan cyclomatic complexcity. Cyclomatic Complexity adalah sebuah software metric yang menyediakan ukuran kuantitatif dari 
kompleksitas logika dari sebuah program[12]. Perhitungan dapat dilakukan dengan rumus

$$
\mathrm{V}(\mathrm{G})=\mathrm{E}-\mathrm{N}+2
$$

dimana nilai $\mathrm{E}$ adalah Edge dan $\mathrm{N}$ adalah Node pada flowgraph. Hasil dari perhitungan sebuah modul dengan cylomatic complexcity didapatkan nilai 3 . Menurut McCabe dalam [13] angka tersebut masuk kedalam kategori Low Risk.

\section{Pengujian Validasi}

Pengujian ini digunakan untuk mengetahui apakah kebutuhan fungsional sistem sudah terpenuhi seperti yang telah rancang sebelumnya.

Tabel 2. Hasil pengujian Validasi

\begin{tabular}{|c|c|c|c|}
\hline No. & Skenario & Ekspektasi hasil & keterangan \\
\hline 1. & $\begin{array}{c}\text { Admin } \\
\text { tambah user }\end{array}$ & $\begin{array}{l}\text { Informasi data } \\
\text { user diperbaharui } \\
\text { dari sistem }\end{array}$ & valid \\
\hline 2. & $\begin{array}{c}\text { Admiin } \\
\text { update user }\end{array}$ & $\begin{array}{l}\text { Informasi data } \\
\text { user diperbaharui } \\
\text { dari sistem }\end{array}$ & valid \\
\hline 3 & $\begin{array}{c}\text { Admin delete } \\
\text { user }\end{array}$ & $\begin{array}{l}\text { Informasi data } \\
\text { user diperbaharui } \\
\text { dari sistem }\end{array}$ & valid \\
\hline 4. & $\begin{array}{l}\text { Admin Lihat } \\
\text { dan buat } \\
\text { Laporan }\end{array}$ & $\begin{array}{l}\text { Informasi data } \\
\text { trasaksi } \\
\text { diperbaharui oleh } \\
\text { system }\end{array}$ & Valid \\
\hline 5 & $\begin{array}{l}\text { Admin } \\
\text { tambah dan } \\
\text { pengurangan } \\
\text { data barang }\end{array}$ & $\begin{array}{l}\text { Informasi data } \\
\text { stok barang } \\
\text { dirperbaharui oleh } \\
\text { sistem }\end{array}$ & Valid \\
\hline
\end{tabular}

Pengujian yang dilakukan terhadap fungsional bernilai valid Hal ini menjadi ukuran bahwa sistem aplikasi sesuai dengan yang diinginkan.

\section{Pengujian Non Fungsional}

Untuk memenuhi penilaian dari kebutuhan non-fungsional dari sistem maka dilakukan pengujian usability. Perhitungan dilakukan menggunakan T-test dengan rumus:
$t=\frac{\bar{D}}{S D / \sqrt{n}}$

$t=$ nilai hitung

$\bar{D}=$ Rata- rata sampel

$\mathrm{SD}=$ Standar Deviasi

$\mathrm{n}=$ jumlah sampel

\section{Uji Hipotesa}

$\mathrm{Ho}=\mu 1-\mu 2=0$

$\mathrm{H} 1=\mu 1-\mu 2 \neq 0$

Uji statistik $t_{h i t}(\mathrm{n}<30), \alpha=0.05$

Wilayah kritik $t_{\text {hit }}<\mathrm{t} \alpha ;(\mathrm{n}-1)$ atau $t_{\text {hit }}>\mathrm{t}$ $\alpha ;(\mathrm{n}-1)$

dari hasil perhitungan didapat $\bar{D}=\frac{72}{10}=7.2$, $\left(\mathrm{S}^{2}\right)=\frac{1}{n-1} \sum_{i=n}^{n}((\mathrm{xj}-\mathrm{xi})-\bar{D})^{2}$

$$
\begin{aligned}
& =\frac{1}{9}(221,2) \\
& =24.57
\end{aligned}
$$

$$
\begin{aligned}
S & =\sqrt{24.79} \\
= & 4.95 \\
t & =\frac{\bar{D}}{S D / \sqrt{n}} \\
& =\frac{7.2}{\frac{4.95}{\sqrt{10}}} \\
& =4,59
\end{aligned}
$$

$t_{\text {hit }}=4.590>t 0,05 ; 9=2,262$ menunjukan aplikasi sistem dapat diterima dan berpengaruh kepada efeksifitas dan efesiensi kerja.

\section{SIMPULAN}

Kegiatan analisis diawali mengisyaratkan akan kebutuhan sebuah sistem aplikasi untuk memudahkan proses kegiatan transaksi dan pengelolaan data user serta data barang.

Melalui konsep ERP dengan mensinergikan dukungan teknologi komputer berupa Bahasa pemrograman Hypertext Preprocessor (PHP), HTML dan konsep Models, View, dan Controller menjadikan sebuah kombinasi yang dapat mengimplementasi proses transaksi sesuai dengan kebutuhan sehingga dapat meningkatkan efektifitas dan efesiensi kerja. 


\section{DAFTAR PUSTAKA}

[1] C. Hardjono, F. Informatika, and U. Telkom, "Perancangan Dan Implementasi Erp ( Enterprise Resource Planning ) Modul Sales and Warehouse Management Pada Cv . Brada," eProceedings Eng., vol. 4, no. 3, pp. 4983-4993, 2017.

[2] I. Gautama, "Relationship Marketing Dan Pemanfaatan Teknologi Informasi Dalam Customer Relationship Management Untuk," vol. 2005, no. Snati, 2005.

[3] S. S. Utami, H. Susilo, and Riyadi, "ANALISIS PENERAPAN ENTERPRISE RESOURCE PLANNING (ERP) (Studi pada PT Domusindo Perdana)," J. Adm. Bisnis, vol. 33, no. 1, pp. 165-170, 2016.

[4] M. Khoiron, "Rancangan Model Sistem ERP pada Perusahaan Sektor Jasa Keuangan," J. Inform., vol. 11, no. 1, p. 46, 2017.

[5] S. Anardani, A. R. Putera, E. R. Planning, V. Chain, and S. Informasi, "Analisa Perancangan Enterprise Resource Planning Pada $\mathrm{Cv}$. Mitra Internusa Jaya Surabaya," vol. 11, no. 2, pp. 80-85, 2017.

[6] R. Al Aziz, F. Amalia, and A. Hendra Brata, "Pembangunan Sistem Enterprise Resource Planning pada Griya Laundry," $J$. Pengemb. Teknol. Inf. dan Ilmu Komput. Univ. Brawijaya, vol. 2, no. 6, pp. 2278-2285, 2018.

[7] F. Tanzil, "Waterfall model," web, 2019. [Online]. Available: http://socs.binus.ac.id/2018/12/21/w aterfall-model/.

[8] S. Wibisono, "Enterprise Resource Planning (ERP) Solusi Sistem Informasi Terintegrasi," J. Teknol. Inf. Din., vol. x, no. 3, pp. 150-159, 2005 .

[9] A. Rukajat, Pendekatan Penelitian kuantitatif, Pertama. Yogyakarta: Deepublish, 2018.

[10] J. Simarmata, Rekayasa Perangkat Lunak. Yogyakarta: Andi Offset, 2010.

[11] Meiliana, "Software Testing :Cyclometic Complexity," Web, 2016. [Online]. Available: http://socs.binus.ac.id/2016/12/29/so ftware-testing-perhitungancyclomatic-complexity/.

[12] M. Cabe, "Cyclomatic Complexity (McCabe) Metric," Gmetrix, 2015. [Online]. Available: http://gmetrics.sourceforge.net/gmet rics-

CyclomaticComplexityMetric.html. 